INTERNATIONAL RESEARCH JOURNAL OF PHARMACY

www.irjponline.com

ISSN $2230-8407$

Research Article

\title{
DEVELOPMENT AND IN-VITRO EVALUATION OF METOPROLOL SUCCINATE CONTROLLED POROSITY OSMOTIC PUMP TABLETS
}

Veeramalla Anil Kumar*, Madishetty Vamshikrishna,Indarapu Rajendra Prasad, Gudikandula Raj Kumar, Kadari Srinivas

Department of Pharmaceutics, Care College of Pharmacy, Warangal, Andhra Pradesh, India

Email: anil198728@gmail.com

Article Received on: 13/02/13 Revised on: 01/03/13 Approved for publication: 17/04/13

DOI: 10.7897/2230-8407.04435

IRJP is an official publication of Moksha Publishing House. Website: www.mokshaph.com

(C) All rights reserved.

\section{ABSTRACT}

In the present research work, attempts were made to develop and evaluate Sustained release formulation of Metoprolol succinate based on osmotic technology.As Metoprolol is a short acting drug, developed formulation provides the advantages of controlled release formulations. The developed formulation provides advantages of less steps of manufacturing procedure, no need of laser drilling, and economical. All of these made the procedure easily amenable to mass production using conventional tablet machines. Metoprolol $50 \mathrm{mg}$ core formulation was prepared using osmogents and coated with different coating formulae to optimize film former (cellulose acetate): pore former (sorbitol) ratio. The effect of different formulation variables namely, membrane weight gain, and amount of pore former in the membrane, were studied. Metoprolol release was inversely proportional to the membrane weight (coating thickness) but directly related to the initial amount of pore former (sorbitol) in the membrane. All polymers and excipients used in optimized formula were found to be compatible with the drug and it was confirmed by FT-IR studies. Drug release from the developed formulations was independent of $\mathrm{pH}$ and agitational intensity. The drug release from formulation was proved as dependent on osmotic pressure only. The number of pores was directly proportional to the amount of pore former in the membrane. The manufactured formulations were stable after 45 days of accelerated stability studies.

KEYWORDS: Sustained release, Controlled release, Metoprolol succinate, Oral osmotic pump, Cellulose acetate membrane, Pore former, Sorbitol.

\section{INTRODUCTION}

From many decades, conventional dosage forms which are of prompt releasing nature, are used for treatment of acute and chronic diseases. The conventional dosage forms provide no control over release of drug. To maintain the drug concentration within the therapeutically effective range, it is often necessary to take these types of conventional dosage forms several times a day. This results in significant fluctuations in drug levels ${ }^{1}$.

Recently, several technical advancements have been made. These have resulted in the development of new techniques in drug delivery. These techniques are capable of controlling the rate of drug delivery, sustaining the duration of therapeutic activity and/or targeting delivery of the drug to a tissue. The role of drug delivery today is to take a therapeutically effective molecule with sub-optimal physicochemical and/or physiological properties and develop an optimized product that will still be therapeutically effective but with added benefits ${ }^{2}$. This is accomplished using the concepts of bioavailability enhancement and controlled release. Incorporating an existing drug into a new drug delivery system can significantly improve its performance in terms of efficacy, safety, and improved patient compliance. ${ }^{3}$

Controlled release pharmaceutical dosage forms may offer one or more advantages over conventional (immediate release) dosage forms of the same drug, including a reduced dosing frequency, a decreased incidence and/or intensity of adverse effects, a greater selectivity of pharmacologic activity, and a reduction in drug plasma fluctuation resulting in a more consistent or prolonged therapeutic effect.

It is advantageous to deliver some drugs with short half- life and which are to be given frequently for chronic ailments, in the form of controlled release formulations. The majority of existing oral controlled release systems are matrix based and their principle drug release mechanism is based on drug diffusion through the matrix system. The diffusion is altered by the $\mathrm{pH}$ of the medium, the presence of food, hydrodynamic conditions, and the body's other physiological factors, all of which can cause difficulty in controlling the drug release rate and result in poor invivo - in vitro correlations (IVIVC) ${ }^{4}$ Another delivery method used is the osmotic drug delivery system, which utilizes the principle of osmotic pressure for the controlled delivery of active agent. The release rate of drug from these systems is independent of the physiological factors of the gastrointestinal tract to a large extent. Osmotic systems have a high degree of IVIVC, because of the factors that are responsible for causing differences in release profiles in in vivo and in vitro (e.g. variable $\mathrm{pH}$, agitation) affect the systems to a much lesser extent. $^{5}$

Metoprolol succinate is a Beta 1-selective (cardio selective) adrenoceptor blocking agent. its chemical name is ( I )(isopropyl amino) -3-(p-(2methoxy ethyl)phenoxyl)-2propanol succinate site in the body to achieve promptly, and then maintain, the desired drug concentration. Metoprolol is a racemic mixture of R- and S- enantiomers, and is primarily metabolized by CYP2D6. when administration orally, it exhibits stereo selective metabolism that is dependent on oxidation phenotype. The purpose of this study was to design oral controlled release tablet formulations of metoprolol Succinate using Cellulose acetate as a coating polymer, different osmotic agents(Mannitol, Fructose),different pore former concentrations. The tablets were prepared by direct compression method, and their physical parameters and in vitro release characteristics were evaluated. The effect of formulation factors such as osmotic pressure of the core tablet (osmogent type and drug/osmogent ratio), the composition of the coating solution, the membrane weight gain percentages, and the concentration of pore-forming agenton the release characteristics was studied in order to optimize these variables.

\section{MATERIALS AND METHODS \\ Materials}

Metoprolol succinate was obtained as a gift sample from RA Chem Ltd, Hyderabad. Acetone NF, Methanol, Fructose, 
Sorbitol, Hydrochloric acid were obtained from S.D Fine Chem Ltd, Mumbai. Cellulose acetate NF, Mannitol, Di butyl phthalate (DBF) from Lupin Pharma Ltd, Pune.Talc and Magnesium stearate, Idacol lake(yellow), High media Laboratories, Microcrystalline cellulose (Avicel pH 101, Strides Pharma Ltd, Bangalore). All other chemicals and ingredients used for study were of Analytical grade.

\section{Methodology \\ Preformulation Study}

Preformulation is defined as that phase of research and development process where physical, chemical and mechanical properties of a drug substance are characterized alone and when combined with excipients, in order to develop stable, safe and effective dosage form. The objective of preformulation studies is to develop a portfolio of information about the drug substance to serve as a set of parameters against which detailed formulation design can be carried out.

A thorough understanding of physicochemical properties may ultimately confirm that no significant barriers are present for the formulation development. The following preformulation studies were performed.

- Drug : Excipient compatibility study

- API characterization

\section{Drug- Excipient Compatibility Studies FT-IR Study}

The pure drug (Metoprolol succinate) and osmogents were subjected to IR studies alone and in combination. Pure drug/combination of drug-osmogent was mixed with $100 \mathrm{mg}$ of potassium bromide. Thorough grinding in smooth mortar can effect mixing. The mixtures were then placed in the sample holder of the instrument. These were analyzed by FTIR to study the interference of osmogents for drug analysis.

\section{Preformulation and Selection of Excipients}

Based on the literature review and compatibility study of API with various inactive ingredients, all excipients were found to be physically compatible with the API.

\section{API Characterization Melting point}

The melting point of the drug sample was determined by open capillaries using melting point apparatus.

\section{Flow properties}

Angle of repose $^{11}$ : Fixed funnel method was used to determine angle of repose. A funnel was fixed to a clamp with its tip at a given height (h), above a flat horizontal surface on which a graph paper was placed. Powder was carefully poured through a funnel till the apex of the conical pile just touches the tip of funnel. The angle of repose was then calculated using the formula,

$$
\operatorname{Tan} \Theta=h / r
$$

Where, $\mathrm{h}=$ the height of the powder cone

$$
\mathrm{r}=\text { the radius of the powder cone }
$$

Bulk density ${ }^{11}$ : Bulk density or apparent density is defined as the ratio of mass of powder to the bulk volume. The presieved blend equivalent to $25 \mathrm{~g}$ was accurately weighed and filled in a $100 \mathrm{ml}$ graduated cylinder and the unsettled volume, $\mathrm{V}_{\mathrm{o}}$ was noted. The bulk density was calculated by the formula
Bulk density $\left(\rho_{0}\right)=\mathrm{M} / \mathrm{V}_{\mathrm{o}}(\mathrm{g} / \mathrm{cc})$

Where, $\mathrm{M}=$ Mass of powder $(\mathrm{g})$

$\mathrm{V}_{\mathrm{o}}=$ Apparent unstirred volume (cc)

Tapped density ${ }^{11}$ Tapped density was determined by using Electrolab USP Apparatus. The pre-sieved blend equivalent to $25 \mathrm{~g}$ was filled in $100 \mathrm{ml}$ graduated cylinder. The mechanical tapping of the cylinder was carried out using tapped density tester at a nominal rate of 300 drops per minute for 500 times initially and the tapped volume $\mathrm{V}_{\mathrm{o}}$ was noted. Tapping was proceeded further for an additional tapping of 750 times and tapped volume $\mathrm{V}_{\mathrm{b}}$ was noted. The difference between two tapped volume was less than $2 \%$, so $\mathrm{V}_{\mathrm{b}}$ was considered as a tapped volume The tapped density was calculated by the formula

$$
\begin{gathered}
\text { Tapped density }\left(\rho_{\mathrm{t}}\right)=\mathrm{M} / \mathrm{V}_{\mathrm{f}}(\mathrm{g} / \mathrm{cc}) \\
\text { Where, } \mathrm{M}=\text { weight of blend }(\mathrm{g}) \\
\mathrm{V}_{\mathrm{f}}=\text { Tapped volume }(\mathrm{cc})
\end{gathered}
$$

Compressibility Index ${ }^{11}$ : Compressibility Index is a measure of flow property of a powder to be compressed as such they are measured for relative importance of interparticulate interactions. The packing ability of drug was evaluated from change in volume, which is due to rearrangement of packing occurring during tapping. It is indicated as Carr's compressibility index (CI). The bulk volume and tapped volume was measured and compressibility index was calculated using the formula.

Compressibility index $(\%)=\left(V_{o}-V_{f}\right) / V_{o}$ X 100 Where, $\mathrm{V}_{\mathrm{o}}=$ Bulk volume $\mathrm{V}_{\mathrm{f}}=$ Tapped volume

Hausner ratio ${ }^{11}$ : Hausner ratio gives an idea regarding the flow of the blend. It is the ratio of tapped density to the apparent density.

$$
\text { HR = Tapped density / Apparent density }
$$

If Hausner's ratio is < 1.25 : good flow of granules $>1.5$ : poor flow of granules

If Hausner's ratio is between 1.25-1.5, flow can be improved by addition of glidants.

Solubility studies: Solubility of drug was determined in buffers of different $\mathrm{pH} 1.2,6.8,7.4$, by placing excess of drug in $50 \mathrm{ml}$ volumetric flask containing $10 \mathrm{ml}$ of buffers. Volumetric flasks were subjected to sonication for $20 \mathrm{~min}$. The samples were filtered through $0.45 \mu$ filters. The aliquots of these solutions are suitably diluted and analyzed using spectrophotometer.

\section{Formulation Development \\ Core formulation}

The development of Controlled Porosity osmotic pump is shown in Table 1.The solubility characteristics of the drug were considered more important in the development of formulations.

\section{Manufacture of Core Tablets}

Core tablets were prepared by direct compression method . Required amounts of drug and Avicel were weighed and passed through sieve \# 60. Then the blend was lubricated with \#60 mesh passed magnesium stearate and talc. The powder blend was compressed on compression machine using $8.0 \mathrm{~mm}$ round standard concave punches. 
In the present work, Avicel $\mathrm{pH} 101$ is used as a tablet diluent, mannitol and fructose as osmogents, magnesium stearate as lubricant, talc as a glidant, and sorbitol as pore former.

\section{Evaluation Tests ${ }^{13}$ \\ Evaluation of core tablet}

Uniformity of weight (Weight variation test): Twenty tablets were randomly selected from each batch and individually weighed. The average weight and standard deviation of twenty tablets were calculated. The batch passes the test for weight variation if the $\%$ deviation is within the permissible limits $(+5 \%)$.

$\%$ Deviation $=$ Individual weight - Average weight $/$ Average weight $\mathrm{x} 100$

\section{Hardness test}

Hardness (diametric crushing strength) is a force required to break a tablet across the diameter. "Hardness factor", the average of the six determinations, was determined and reported. Hardness indicates the strength of tablet. The force is measured in $\mathrm{kg} / \mathrm{cm}^{2}$. Hardness is measured using Monsanto hardness tester.

\section{Friability}

Friability is the loss of weight of tablet in the container/package, due to removal of fine particles from the surface. The permitted friability limit is $1.0 \%$.A sample of 10 whole tablets were taken and placed in a Roche friabilator and rotated for 100 times at $25 \mathrm{rpm}$ and tablets were removed dedusted and weighed again. The $\%$ friability was measured using the below formula.

$$
\% \text { Friability }=\frac{W_{1}-W_{2}}{W_{1}} \times 100
$$

Where, W1 = Initial weight of the tablets W2 $=$ Weight of tablets after test

\section{Thickness}

Three samples were selected randomly from each batch and thickness was measured using Vernier calipers.

\section{Drug content}

Twenty tablets were randomly selected, average weight was calculated and powdered in a mortar. Powder equivalent to $100 \mathrm{mg}$ of drug was weighed accurately and transferred to $100 \mathrm{ml}$ volumetric flask, added $50 \mathrm{ml}$ of $0.1 \mathrm{~N}$ hydrochloric acid and sonicated for $20 \mathrm{~min}$. Then, the volume was made up to mark. The solution was filtered through $0.45 \mu$ nylon membrane filter. The filtrate was diluted suitably using $0.1 \mathrm{~N}$ hydrochloric acid and the drug content was estimated by UV spectrophotometer at $\lambda_{\max }$ of $274 \mathrm{~nm}$ against blank and reported. The content uniformity should be not less than $90 \%$ and not more than $110 \%$ of the labeled value.

\section{Coating of CPOP Tablets}

Release of the drug from the osmotic pump tablets is mainly dependent on its coating membrane which is responsible for creating osmotic pressure inside the device. Release can be controlled by optimizing cellulose acetate and pore former in the coating membrane and the delivery orifice created on the membrane.

Efforts were made to control the drug release by optimizing composition of coating solution, thickness of semipermeable membrane as they can modify the drug release.
Selection of solvent and pore former concentration for coating solution

$3 \% \mathrm{w} / \mathrm{v}$ cellulose acetate was prepared in different solvents viz. DCM: methanol (80:20) and Acetone:Methanol(80:20). These solutions were divided into five parts. To each part of these solutions different concentrations of PEG 400 and DBP $(0,5,10,15,20 \% \mathrm{w} / \mathrm{w}$ of cellulose acetate) were added and mixed well using mechanical stirrer. The resultant solutions were poured into petri dishes and allowed to dry in a tray dryer at $45^{\circ} \mathrm{C}$ overnight. Films were tested for appearance and integrity. Based on the appearance and integrity, a solution of Acetone:Methanol (80:20) mixture containing DBP was selected.

Preparation of coating solution: Required quantity of cellulose acetate was accurately weighed and dissolved in a beaker containing acetone using mechanical stirrer. The stirring was continued till a clear solution was formed and DBP was added slowly to the beaker with stirring. Sorbitol was separately dissolved in a beaker containing measured quantity of Methanol and was added slowly to the cellulose acetate mixture with stirring. The selected formula of coating solution is shown in Table 3.

Coating procedure: Core tablets were placed in a coating pan along with $200 \mathrm{mg}$ of filler tablets. The coating pan was rotated at $12 \mathrm{rpm}$ and heated air was passed through the tablet bed. Coating process was started when the outlet air temperature reaches to $33{ }^{\circ} \mathrm{C}$. Coating solution was sprayed at the rate of $2-4 \mathrm{ml} / \mathrm{min}$ and atomizing air pressure was kept at $2.0 \mathrm{~atm}$. The outlet temperature was maintained above 33 ${ }^{\circ} \mathrm{C}$ by keeping the inlet air temperature in the range of 45-50 ${ }^{\circ} \mathrm{C}$. Coating was continued until desired weight gain was obtained on the core tablets. The coated tablets were dried at $50{ }^{\circ} \mathrm{C}$ overnight in a tray dryer.

\section{Evaluation of Coated Tablets}

Percentage weight gain: 10 core tablets were randomly selected subjected to coating. The initial weight of 10 uncoated tablets was recorded. After period of coating, spraying of coating solution was stopped and allowed to dry for $10-15 \mathrm{~min}$, in the coating pan at $45{ }^{\circ} \mathrm{C}$ to remove the majority of solventmoisture. The weight of 10 coated tablets was recorded. The percent weight gain was calculated. Samples were collected for predetermined weight gain (approximately). The sample of coated tablets was subjected for overnight drying in tray drier $45^{\circ} \mathrm{C}$ to remove complete solvent. The dried tablets were weighed again and $\%$ weight gain was calculated accurately.

\section{In-vitro Drug Release}

Apparatus: USP-type II dissolution apparatus (paddle type)

Medium: $0.1 \mathrm{~N} \mathrm{HCl} \mathrm{pH} \mathrm{1.2} \mathrm{Phosphate} \mathrm{buffer} \mathrm{pH} 6.8$

Volume of medium: $500 \mathrm{ml}$

Apparatus: USP II (Paddle) apparatus

RPM: 50

Temperature: $37 \pm 0.5^{0} \mathrm{c}$

Sample points: 1 hour

Sample volume: $5 \mathrm{ml}$

Replacement volume: $5 \mathrm{ml}$

Collected samples were analyzed at $274 \mathrm{~nm}$ using $0.1 \mathrm{~N}$ hydrochloric acid as blank for the first $2 \mathrm{~h}$ samples and at 274 nm using phosphate buffer $\mathrm{pH} 6.8$ as a blank for rest of the samples. The percentage cumulative drug release (\% CDR) was calculated. 
Effect of Various Parameters on d $\backslash$ Drug Release

Effect of \% Weight Gain: The \% weight gain in the coating formulation was varied and its effect on the drug release was evaluated. The tablets were coated to achieve a weight gain of 6,8 , and $10 \%$. All these tablets were subjected for dissolution studies using USP II (paddle type) apparatus as per procedure specified in the previous sections from in-vitro release studies.

Effect of pH: In order to study the effect of $\mathrm{pH}$ and to assure a reliable performance of the developed formulations independent of $\mathrm{pH}$, release studies of the optimized formulations were conducted in various mediums of varying $\mathrm{pH}(0.1 \mathrm{~N} \mathrm{HCl}$, phosphate buffer $\mathrm{pH} 6.8$ and $\mathrm{pH}$ 7.4).
Dissolution apparatus used was paddle type (USP-II) at 50 $\mathrm{rpm}$ for $12 \mathrm{~h}$. The samples $(5 \mathrm{ml})$ were withdrawn at predetermined intervals and analyzed.

\section{Drug Release Kinetics}

To study the release kinetics, data obtained from in vitro drug release studies were plotted in various kinetic models: Zero Order as cumulative percentage of drug unreleased vs. time, First Order as log cumulative percentage of drug remaining vs. time, Hixson-Crowell Cube Root Law Model as the cube root of the percentage of drug remaining in the matrix vs. time, and Higuchi Model as the square root of time vs. $\%$ drug release.

TABLE 1: FORMULATION TRIALS WITH MANNITOL

\begin{tabular}{|c|c|c|c|c|c|c|c|c|c|}
\hline \multirow[t]{2}{*}{ Ingredients } & \multicolumn{9}{|c|}{ Weight (in mg) } \\
\hline & F1 & $\mathrm{F} 2$ & F3 & F4 & F5 & F6 & F7 & F8 & F9 \\
\hline & \multicolumn{9}{|c|}{ Core Tablet Formulation } \\
\hline Drug & 50 & 50 & 50 & 50 & 50 & 50 & 50 & 50 & 50 \\
\hline Mannitol & 50 & 50 & 50 & 100 & 100 & 100 & 150 & 150 & 150 \\
\hline Avicel PH101 & 145 & 145 & 145 & 95 & 95 & 95 & 45 & 45 & 45 \\
\hline Mg.Stearate & 2.5 & 2.5 & 2.5 & 2.5 & 2.5 & 2.5 & 2.5 & 2.5 & 2.5 \\
\hline Talc & 2.5 & 2.5 & 2.5 & 2.5 & 2.5 & 2.5 & 2.5 & 2.5 & 2.5 \\
\hline \multirow[t]{2}{*}{ Total Weight } & 250 & 250 & 250 & 250 & 250 & 250 & 250 & 250 & 250 \\
\hline & \multicolumn{9}{|c|}{ Coating Formulation(w/v) } \\
\hline Cellulose Acetate & $3 \%$ & $3 \%$ & $3 \%$ & $3 \%$ & $3 \%$ & $3 \%$ & $3 \%$ & $3 \%$ & $3 \%$ \\
\hline DBP* & $10 \%$ & $10 \%$ & $10 \%$ & $10 \%$ & $10 \%$ & $10 \%$ & $10 \%$ & $10 \%$ & $10 \%$ \\
\hline Sorbitol* & $0 \%$ & $10 \%$ & $20 \%$ & $0 \%$ & $10 \%$ & $20 \%$ & $0 \%$ & $10 \%$ & $20 \%$ \\
\hline Solvent & \multicolumn{9}{|c|}{ Acetone:Methanol $(80: 20)$} \\
\hline
\end{tabular}

Drug $=$ Metoprolol succinate. ${ }^{*} \mathrm{w} / \mathrm{w}$ of CA

TABLE 2: FORMULATION TRIALS WITH FRUCTOSE

\begin{tabular}{|c|c|c|c|c|c|c|}
\hline \multirow[t]{2}{*}{ Ingredients } & \multicolumn{6}{|c|}{ Weight(in mg) } \\
\hline & F10 & F11 & F12 & F13 & F14 & F15 \\
\hline & \multicolumn{6}{|c|}{ Core Tablet Formulation } \\
\hline Drug & 50 & 50 & 50 & 50 & 50 & 50 \\
\hline Fructose & 50 & 50 & 50 & 100 & 100 & 100 \\
\hline Avicel PH101 & 145 & 145 & 145 & 95 & 95 & 95 \\
\hline Mg.Stearate & 2.5 & 2.5 & 2.5 & 2.5 & 2.5 & 2.5 \\
\hline Talc & 2.5 & 2.5 & 2.5 & 2.5 & 2.5 & 2.5 \\
\hline \multirow[t]{2}{*}{ Total Weight } & 250 & 250 & 250 & 250 & 250 & 250 \\
\hline & \multicolumn{6}{|c|}{ Coating Formulation(w/v) } \\
\hline Cellulose Acetate & $3 \%$ & $3 \%$ & $3 \%$ & $3 \%$ & $3 \%$ & $3 \%$ \\
\hline DBP* & $10 \%$ & $10 \%$ & $10 \%$ & $10 \%$ & $10 \%$ & $10 \%$ \\
\hline Sorbitol* & $0 \%$ & $10 \%$ & $20 \%$ & $0 \%$ & $10 \%$ & $20 \%$ \\
\hline Solvent & \multicolumn{6}{|c|}{ Acetone:Methanol(80:20) } \\
\hline
\end{tabular}

Drug $=$ Metoprolol succinate, ${ }^{*} \mathrm{w} / \mathrm{w}$ of CA

TABLE 3: FORMULA FOR COATING SOLUTION

\begin{tabular}{|c|c|}
\hline Ingredients & Quantity \\
\hline Cellulose acetate & $3 \% \mathrm{w} / \mathrm{v}$ \\
\hline DBP & $10 \% \mathrm{w} / \mathrm{w}$ of CA \\
\hline Sorbitol & $0,10,20 \mathrm{w} / \mathrm{w}$ of CA \\
\hline Acetone : Methanol & $80: 20$ \\
\hline
\end{tabular}

TABLE 4 : FLOW PROPERTIES OF THE DRUG

\begin{tabular}{|c|c|}
\hline Parameter & Result \\
\hline Bulk density $(\mathrm{gm} / \mathrm{cc})$ & $0.440 \pm 0.050$ \\
\hline Tapped density $(\mathrm{gm} / \mathrm{cc})$ & $0.712 \pm 0.025$ \\
\hline Compressibility index $(\%)$ & $38 \pm 0.065$ \\
\hline Hausners ratio & 1.618 \\
\hline
\end{tabular}

TABLE 5: SOLUBILITY STUDY OF THE DRUG

\begin{tabular}{|c|c|}
\hline Media & Solubility (mg/ml) \\
\hline Purified water & 15 \\
\hline 0.1 N HCl, pH 1.2 & 16.4 \\
\hline Phosphate buffer, pH 6.8 & 17.2 \\
\hline
\end{tabular}


Veeramalla Anil Kumar et al. Int. Res. J. Pharm. 2013, 4 (4)

TABLE 6: EVALUATION OF PRE COMPRESSION PARAMETERS OF FORMULATIONS CONTAINING 1:1,1:2 DRUG:OSMOGENT RATIO BY USING MANNITOL AS OSMOGENT

\begin{tabular}{|c|c|c|c|c|c|}
\hline Formulation & Angle of repose & $\begin{array}{l}\text { Bulk density } \\
\quad\left(\mathrm{gm} / \mathrm{cc}^{3}\right)\end{array}$ & $\begin{array}{l}\text { Tapped } \\
\text { density } \\
\left(\mathrm{gm} / \mathrm{cc}^{3}\right)\end{array}$ & Carr's index (\%) & Hausner's ratio \\
\hline F1 & $28.54 \pm 1.8$ & 0.427 & 0.577 & 14.789 & 1.35 \\
\hline F3 & $32.22 \pm 1.5$ & 0.412 & 0.646 & 25.125 & 1.56 \\
\hline F4 & $36.25 \pm 1.2$ & 0.523 & 0.623 & 21.940 & 1.47 \\
\hline F5 & $35.34 \pm 1.2$ & 0.489 & 0.634 & 17.23 & 1.23 \\
\hline
\end{tabular}

TABLE 7: EVALUATION OF PRE COMPRESSION PARAMETERS OF FORMULATIONS CONTAINING 1:3 DRUG:OSMOGENTRATIO BY USING MANNITOL AS OSMOGENT

\begin{tabular}{|c|c|c|c|c|c|}
\hline Formulation & Angle of repose & $\begin{array}{c}\text { Bulk density } \\
\left(\mathbf{g m} / \mathbf{c c}^{\mathbf{3}} \mathbf{)}\right.\end{array}$ & $\begin{array}{c}\text { Tapped } \\
\mathbf{d e n s i t y} \\
\left(\mathbf{g m} / \mathbf{c c}^{\mathbf{3}}\right)\end{array}$ & Carr's index (\%) & Hausner's ratio \\
\hline F7 & $35.34 \pm 1.2$ & 0.462 & 0.629 & 15.21 & 1.43 \\
\hline F8 & $26.37 \pm 1.0$ & 0.494 & 0.648 & 14.69 & 1.54 \\
\hline F9 & $29.54 \pm 1.8$ & 0.421 & 0.678 & 12.25 & 1.35 \\
\hline
\end{tabular}

TABLE 8: EVALUATION OF PRE COMPRESSION PARAMETERS OF FORMULATIONS CONTAINING 1:1,1:2 DRUG:OSMOGENT RATIO BY USING FRUCTOSE AS OSMOGENT

\begin{tabular}{|c|c|c|c|c|c|}
\hline Formulation & Angle of repose & $\begin{array}{l}\text { Bulk density } \\
\quad\left(\mathrm{gm} / \mathrm{cc}^{3}\right)\end{array}$ & $\begin{array}{l}\text { Tapped } \\
\text { density } \\
\left(\mathrm{gm} / \mathrm{cc}^{3}\right)\end{array}$ & Carr's index (\%) & Hausner's ratio \\
\hline F10 & $20.11 \pm 1.1$ & 0.558 & 0.697 & 12.23 & 1.246 \\
\hline F12 & $28.11 \pm 1.1$ & 0.436 & 0.663 & 12.25 & 1.40 \\
\hline F13 & $33.73 \pm 1.0$ & 0.469 & 0.709 & 14.98 & 1.59 \\
\hline F14 & $38.21 \pm 1.9$ & 0.588 & 0.686 & 12.56 & 1.48 \\
\hline
\end{tabular}

TABLE 9: COATING COMPOSITION FOR ALL THE FORMULATIONS

\begin{tabular}{|c|c|}
\hline Ingredients & Composition \\
\hline Cellulose acetate & $3 \% \mathrm{w} / \mathrm{v}$ \\
\hline Di butyl phthalate & $10 \% \mathrm{w} / \mathrm{w}$ of CA \\
\hline Acetone: Methanol & $80: 20$ \\
\hline$\%$ coating & $8 \%$ \\
\hline
\end{tabular}

TABLE 10: EVALUATION OF POST COMPRESSION PARAMETERS OF FORMULATIONS CONTAINING 1:1,1:2 DRUG:OSMOGENT RATIO BY USING MANNITOL AS OSMOGENT

\begin{tabular}{|c|c|c|c|c|}
\hline Formulation & Weight variation(mg) & Thickness* (mm) & Hardness* $\left(\mathrm{kg} / \mathrm{cm}^{2}\right)$ & Friability(\%) \\
\hline F1 & $252.16 \pm 4.61$ & $3.37 \pm 0.04$ & $7.85 \pm 0.54$ & 0.09 \\
\hline F2 & $249.48 \pm 2.76$ & $3.38 \pm 0.11$ & $6.20 \pm 0.61$ & 0.06 \\
\hline F3 & $251.82 \pm 3.33$ & $3.14 \pm 0.03$ & $6.02 \pm 0.62$ & 0.06 \\
\hline F4 & $250.83 \pm 4.46$ & $3.25 \pm 0.03$ & $7.72 \pm 0.51$ & 0.11 \\
\hline F5 & $251.33 \pm 5.32$ & $3.42 \pm 0.02$ & $6.20 \pm 0.61$ & 0.07 \\
\hline F6 & $249.67 \pm 4.36$ & $3.38 \pm 0.02$ & $6.02 \pm 0.62$ & 0.04 \\
\hline
\end{tabular}

TABLE 11: EVALUATION OF PRE COMPRESSION PARAMETERS OF FORMULATIONS CONTAINING 1:3 DRUG:OSMOGENT RATIO BY USING MANNITOL AS OSMOGENT

\begin{tabular}{|c|c|c|c|c|}
\hline Formulation & Weight variation (mg) & Thickness* (mm) & Hardness* $\left(\mathrm{kg} / \mathrm{cm}^{2}\right)$ & Friability $(\%)^{\#}$ \\
\hline F7 & $248.5 \pm 5.82$ & $3.36 \pm 0.20$ & $7.65 \pm 0.39$ & 0.08 \\
\hline F8 & $252.52 \pm 3.87$ & $3.44 \pm 0.16$ & $7.82 \pm 0.056$ & 0.08 \\
\hline F9 & $251.17 \pm 7.83$ & $3.43 \pm 0.05$ & $7.85 \pm 0.54$ & 0.12 \\
\hline
\end{tabular}

TABLE 12: EVALUATION OF PRE COMPRESSION PARAMETERS OF FORMULATIONS CONTAINING 1:1,1:2 DRUG:OSMOGENT RATIO BY USING FRUCTOSE AS OSMOGENT

\begin{tabular}{|c|c|c|c|c|}
\hline Formulation & Weight variation $\mathbf{( m g )}$ & Thickness* $^{\#}(\mathbf{m m})$ & Hardness* $\left.^{*} \mathbf{k g} / \mathbf{c m}^{\mathbf{2}}\right)$ & Friability (\%) $^{\#}$ \\
\hline F10 & $250.33 \pm 5.82$ & $3.54 \pm 0.02$ & $9.350 \pm 1.57$ & 0.12 \\
\hline F11 & $252.17 \pm 7.83$ & $3.184 \pm 0.04$ & $6.03 \pm 0.68$ & 0.20 \\
\hline F12 & $249.57 \pm 4.61$ & $3.55 \pm 0.11$ & $7.38 \pm 0.79$ & 0.16 \\
\hline F13 & $251.52 \pm 2.76$ & $3.42 \pm 0.12$ & $9.13 \pm 0.53$ & 0.18 \\
\hline F14 & $249.57 \pm 2.76$ & $3.28 \pm 0.12$ & $6.57 \pm 0.75$ & 0.20 \\
\hline F15 & $251.71 \pm 2.93$ & $3.33 \pm 0.19$ & $7.42 \pm 1.25$ & 0.16 \\
\hline
\end{tabular}


Veeramalla Anil Kumar et al. Int. Res. J. Pharm. 2013, 4 (4)

TABLE 13. EVALUATION OF COATED TABLETS CONTAINING 1:1,1:2 DRUG:OSMOGENT RATIO BY USING MANNITOL AS OSMOGENT

\begin{tabular}{|c|c|c|c|}
\hline Formulation & Weight variation(mg) $^{\#}$ & Thickness* (mm) $^{*}$ & Drug Content (\%)** $^{*}$ \\
\hline F1 & $273.84 \pm 2.45$ & $3.74 \pm 0.044$ & $100.92 \pm 0.39$ \\
\hline F2 & $267.44 \pm 3.75$ & $3.84 \pm 0.117$ & $97.527 \pm 1.87$ \\
\hline F3 & $273.22 \pm 4.26$ & $3.48 \pm 0.038$ & $102.40 \pm 0.41$ \\
\hline F4 & $268.58 \pm 4.28$ & $3.45 \pm 0.039$ & $99.20 \pm 1.52$ \\
\hline F5 & $274.20 \pm 3.45$ & $3.56 \pm 0.254$ & $98.21 \pm 0.15$ \\
\hline
\end{tabular}

\# Results of one batch, * Each value is an average of six determinations, ** Each value is an average of three determinations

TABLE 14: EVALUATION OF COATED TABLETS CONTAINING 1:3 DRUG:OSMOGENT RATIO BY USING MANNITOL AS OSMOGENT

\begin{tabular}{|c|c|c|c|}
\hline Formulation & Weight variation(mg) & Thickness* (mm) $^{*}$ & Drug Content (\%)** \\
\hline F7 & $271.66 \pm 5.62$ & $3.72 \pm 0.20$ & $100.92 \pm 0.39$ \\
\hline F8 & $269.74 \pm 4.98$ & $3.84 \pm 0.16$ & $97.527 \pm 1.87$ \\
\hline F9 & $274.57 \pm 7.25$ & $3.93 \pm 0.05$ & $102.40 \pm 0.41$ \\
\hline
\end{tabular}

\# Results of one batch, * Each value is an average of six determinations, ** Each value is an average of three determinations

TABLE 15: EVALUATION OF COATED TABLETS CONTAINING 1:1,1:2 DRUG:OSMOGENT RATIO BY USING FRUCTOSE AS OSMOGENT

\begin{tabular}{|c|c|c|c|}
\hline Formulation & Weight variation(mg) $^{\#}$ & Thickness* $\left.^{*} \mathbf{m m}\right)$ & Drug Content (\%)** \\
\hline F10 & $267.47 \pm 2.65$ & $3.87 \pm 0.044$ & $99.201 \pm 1.53$ \\
\hline F11 & $270.07 \pm 1.45$ & $3.75 \pm 0.03$ & $98.27 \pm 0.05$ \\
\hline F12 & $269.31 \pm 2.21$ & $3.70 \pm 0.05$ & $101.25 \pm 1.58$ \\
\hline F13 & $271.2 \pm 1.59$ & $3.98 \pm 0.65$ & $98.54 \pm 0.98$ \\
\hline F14 & $270.15 \pm 2.89$ & $3.45 \pm 0.55$ & $101.94 \pm 0.52$ \\
\hline F15 & $270.33 \pm 1.25$ & $3.67 \pm 0.18$ & $98.60 \pm 0.42$ \\
\hline
\end{tabular}

\# Results of one batch, * Each value is an average of six determinations, ** Each value is an average of three determinations

TABLE 16. COMPARISION OF CUMULATIVE PERCENTAGE DRUG RELEASE OPTIMIZED PRODUCT WITH MARKETED PRODUCT

\begin{tabular}{|c|c|c|}
\hline \multirow{2}{*}{ Time (h) } & \multicolumn{2}{|c|}{ \% Cumulative drug release* } \\
\cline { 2 - 3 } & Optimized (F6) & Marketed product \\
\hline 1 & $19.4 \pm 0.754$ & $18.3 \pm 0.55$ \\
\hline 2 & $23.4 \pm 1.206$ & $26.8 \pm 0.35$ \\
\hline 3 & $29.4 \pm 0.460$ & $37.3 \pm 0.45$ \\
\hline 4 & $35.4 \pm 0.731$ & $45.6 \pm 0.43$ \\
\hline 5 & $39.4 \pm 1.262$ & $56.2 \pm 0.41$ \\
\hline 6 & $45.1 \pm 1.029$ & $64.5 \pm 0.31$ \\
\hline 7 & $53.8 \pm 0.689$ & $72.4 \pm 0.57$ \\
\hline 8 & $59.2 \pm 0.701$ & $76.3 \pm 0.46$ \\
\hline 9 & $68.5 \pm 0.741$ & $82.3 \pm 0.45$ \\
\hline 10 & $76.5 \pm 0.645$ & $86.2 \pm 0.38$ \\
\hline 11 & $83.9 \pm 0.944$ & $91.3 \pm 0.57$ \\
\hline 12 & $95.3 \pm 0.606$ & $95.2 \pm 0.42$ \\
\hline
\end{tabular}

TABLE 17: COMPARISON OF ORDERS OF IN VITRO RELEASE OF THE DRUG FROM THE FORMULATION F6

\begin{tabular}{|c|c|c|}
\hline Release kinetics /Release mechanism & $\mathbf{R}^{\mathbf{2}}$ value & Regression equation \\
\hline Zero-order kinetics & 0.984 & $\mathrm{y}=8.387 \mathrm{x}+5.968$ \\
\hline First-order kinetics & 0.975 & $\mathrm{y}=0.064 \mathrm{x}+2.008$ \\
\hline Higuchi model & 0.956 & $\mathrm{y}=25.20 \mathrm{x}-6.143$ \\
\hline Koresmeyerpeppas & 0.996 & $\mathrm{y}=0.660 \mathrm{x}+1.228$ \\
\hline Hixson-Crowell cube root model & 0.987 & $\mathrm{y}=-0.188 \mathrm{x}+4.616$ \\
\hline
\end{tabular}

Stability studies:

TABLE 18. STABILITY STUDIES OF OPTIMIZED FORMULATION (F6) AT TEMPERATURE 30 $\pm 20^{\circ} \mathrm{C}$

\begin{tabular}{|c|c|c|c|c|c|}
\hline \multirow[t]{2}{*}{ Parameters } & \multirow[t]{2}{*}{ Specifications } & \multicolumn{4}{|c|}{ Test Condition $\mathbf{3 0} \pm \mathbf{2}^{\mathbf{0}} \mathbf{C}$} \\
\hline & & Initial & 15 Days & 30 Days & 45 Days \\
\hline Description & Yellow round shaped tablets. & Comply & Comply & Comply & Comply \\
\hline Assay & NLT $90 \% \&$ NMT $110 \%$ of labelled amount of drug. & 100.5 & 99.89 & 99.87 & 99.87 \\
\hline
\end{tabular}

TABLE 19. STABILITY STUDIES OF OPTIMIZED FORMULATION (F6) AT TEMPERATURE 40 $\pm 20^{\circ} \mathrm{C}$

\begin{tabular}{|c|c|c|c|c|c|}
\hline \multirow[t]{2}{*}{ Parameters } & \multirow[t]{2}{*}{ Specifications } & \multicolumn{4}{|c|}{ Test Condition (Accelerated) $40 \pm 2^{0} \mathrm{C}$} \\
\hline & & Initial & 15 Days & 30 Days & 45 Days \\
\hline Description & Yellow round shaped tablets. & Comply & Comply & Comply & Comply \\
\hline Assay & NLT $90 \% \&$ NMT $110 \%$ of labelled amount of drug. & 99.83 & 99.54 & 99.41 & 99.39 \\
\hline
\end{tabular}




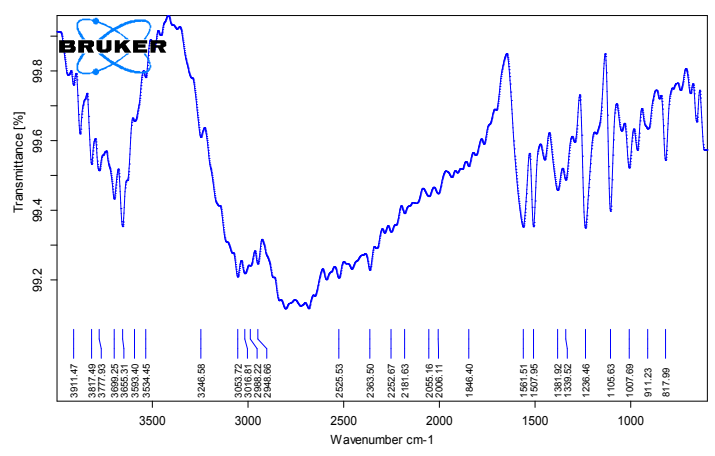

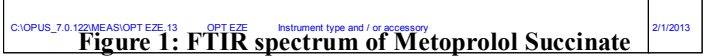

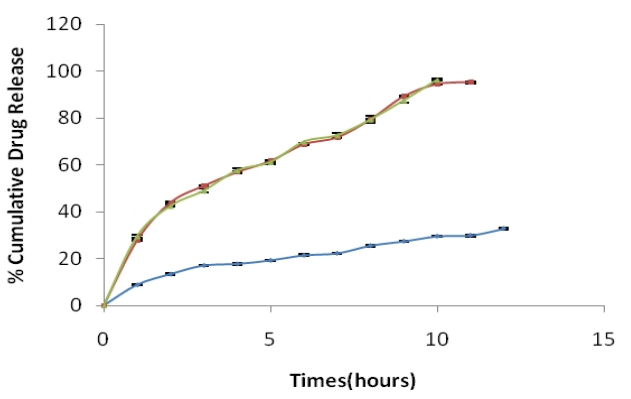

Figure 3: In-vitro drug release of the drug from tablets of batches F7 to F9

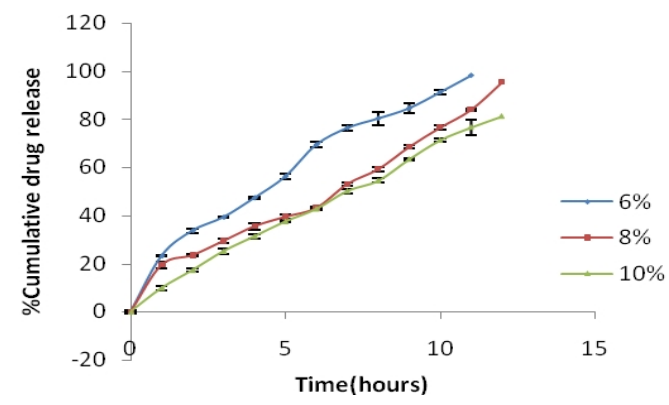

Figure 5: In-vitro drug release profile of $\mathrm{F} 6$ at different $\%$ weight gain

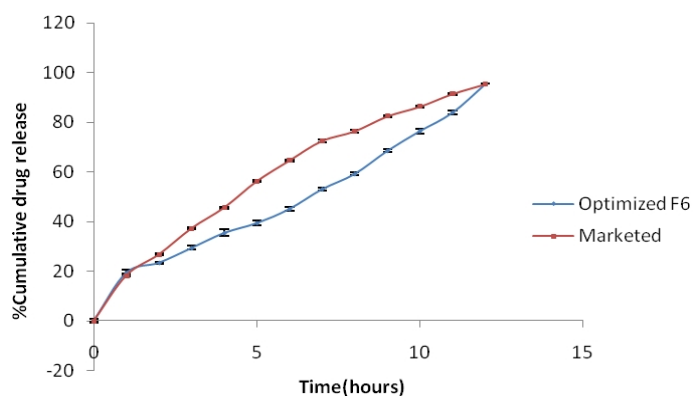

Figure 7: Dissolution profiles of optimized formulation (F6) and Marketed formulation

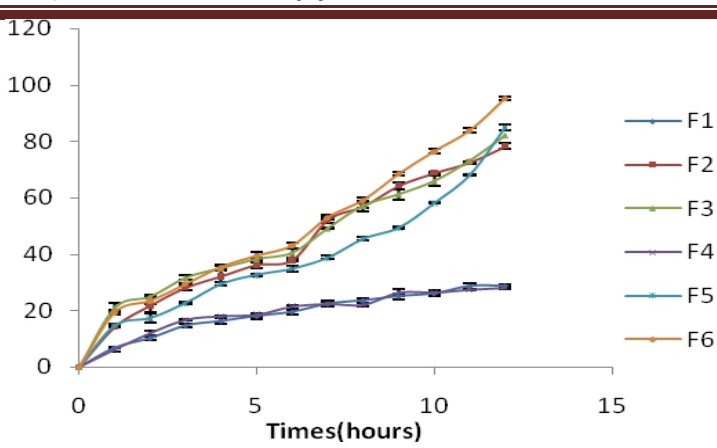

Figure 2: In-vitro drug release of the drug from tablets of batches F1 to F6

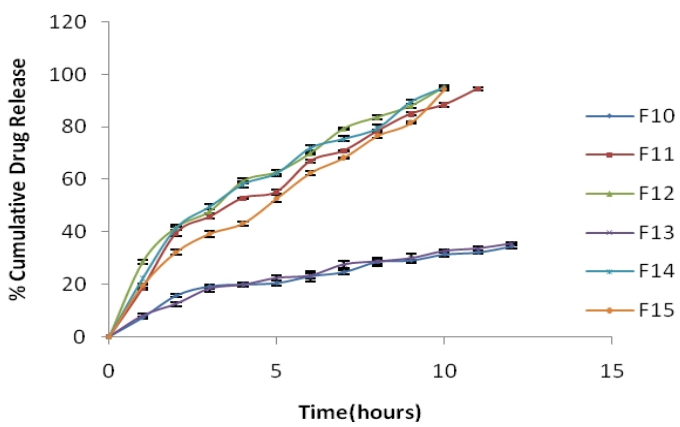

Figure 4 : In-vitro drug release of the drug from tablets of batches F10 F15

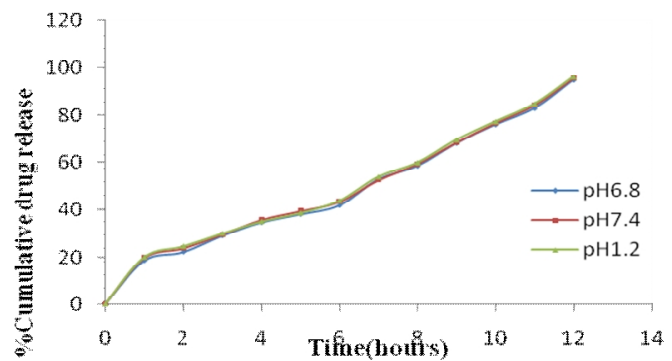

Figure 6: In-vitro drug release profile of $\mathrm{F} 6$ in media of different pH

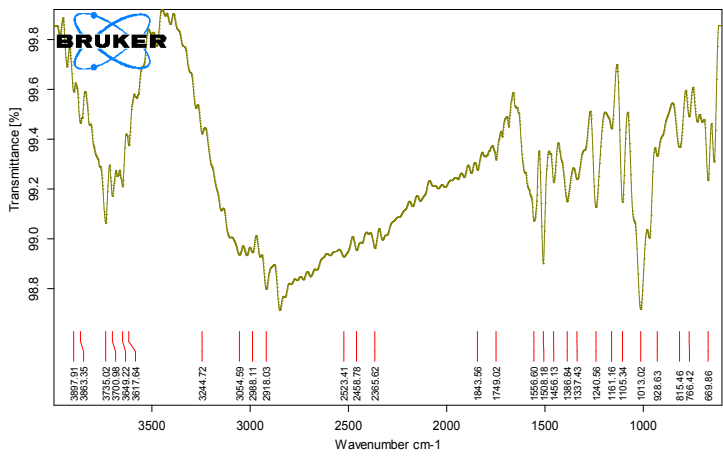

Figure 7: FTIR spectrum of Optimized Formulation 
RESULTS AND DISCUSSIONS

Preformulation study

FT-IR studies: FTIR studies were carried out to confirm the compatibility of the excipients with the drug used in the formulation. The FTIR scans for the pure drug and for mixtures of drug and different excipients. There is no significant change in the peaks of drug-excipient mixtures in comparison to pure drug, indicating that there is no incompatibility of excipients with the drug.

\section{API characterization}

Melting point: The melting point of the drug sample was found to be 135 with reference to the literature it was found to be $137^{\circ} \mathrm{C}$. The drug sample showed compliance with the data given in merck index, which reflects its quality and purity.

Flow properties: The flow properties of the pure drug were determined and the data is reported in the Table 4. From the Table, it is observed that the drug showed poor flow properties and poor compressibility characteristics.

Solubility studies: The solubility of drug was determined in the water and in different buffer solutions of $\mathrm{pH} 1.2$ to 6.8 and results were tabulated in the Table 5.

\section{Formulation Development}

Core Formulation :The pre-compression properties of the blend were reported in Table 7,8,9 and the parameters evaluated for the core tablets are given in the tables $9,10,11$,

\section{Coating composition for the all formulations}

In all the coating formulae of tablets, cellulose acetate (water insoluble film-forming polymer) Dibutyl pthalate (plasticizers), sorbitol (poreforming agent) were used. Different coating formulae were developed by changing the ratio of pore forming agent Then coated tablets were subjected for the $8 \%$ weight gain. These coated tablets were subjected to in vitro dissolution. The properties of the coated tablets are shown in the Tables 12,13,and14.

\section{In-vitro drug release study}

The \% cumulative drug release in F1-F3 was found to be in the range of $0-80 \%$ in $12 \mathrm{~h}$, i.e the osmogent ratio was incapable to create desired osmotic gradient. However, the formulation F3 showed the release up to $82 \%$, hence the Mannitol was chosen as an osmogent for further studies with increased concentrations to create sufficient osmotic gradient and increased concentrations of sorbitol to create sufficient pores for release of drug.

Formulation F4 to F6 showed increased drug release with increased drug osmogent ratio and level of pore former. Formulation F6 showed desired drug release which was upto $95.36 \%$ in 12 hours.

It was found to be the drug release was increased with increased osmogent concentration. The formulation F7 has shown lowest drug release (32\%) in $12 \mathrm{~h}$; because of no pore forming agent added in the coating solution. Whereas F8 and F9 has shown the highest drug release within $11 \mathrm{hrs}$.

The formulation F15 has shown highest drug release (95\%) in $10 \mathrm{~h}$. This increased drug release from the formulations F10 to F15 could be accounted for higher levels of Fructose, which has high osmotic pressure than mannitol, creates sufficient osmotic pressure.
In the absence of Sorbitol( $0 \%)$, the drug release was less due to low number of pores and in the presence of high amount of Sorbitol $(20 \%)$, the pores might formed which enhance the drug release from the tablets due to high amount of sorbitol leaches from the membrane.

\section{Effect of Various Parameters on Drug Release} In-vitro drug release profile of $\mathrm{F} 6$ at different \% weight gain

Core tablets of Metoprolol succinate of batch F6 were coated so as to get tablets with different weight gain $(6,8,10 \%$ $\mathrm{w} / \mathrm{w})$. Release profile of drug from these formulations is shown in Figure 32 . It is clearly evident that drug release decreases with an increase in weight gain of the coating membrane. No bursting of tablet was observed during the dissolution in any formulation.

\section{In-vitro drug release profile of $\mathrm{F} 6$ at different $\mathrm{pH}$}

The invitro drug dissolution studies of marketed product and optimized formulation was carried out in different $\mathrm{pH}$ media $0.1 \mathrm{~N} \mathrm{HCl}, \mathrm{pH} 6.8$, and in 7.4. The marketed product showed the $95.2 \%$ drug release in 12 hours and followed first order where as the optimized formulation F6 shows the $95.36 \%$ drug release in 12 hours and fallowed zero order release from these results it is confirmed that optimized formulation is better than the marketed product.

\section{Kinetics of In vitro Drug Release}

The optimized coated F6 formulations followed Zero order release kinetics. The in-vitro release data were processed as per Higuchi's model and Hixon - Crowell Cube root models. The equations were generated through statistical procedures and reported in Table 15.

$\mathrm{R}^{2}$ values are higher for Hixson - Crowell Cube root model from optimized formulation F6 hence followed osmotic mechanism.

\section{Stability Studies}

Stability studies for the optimized tablets were carried out at a temperature of $40^{\circ} \pm 2^{\circ} \mathrm{C}$ and $30 \pm 2^{\circ} \mathrm{C}$ for a period of 45 days. Tablets are evaluated for physical appearance, assay. An average drug content of the tablets were $99.95 \% \mathrm{w} / \mathrm{w}$ and $99.51 \% \mathrm{w} / \mathrm{w}$. Tablets have not shown any significant change during storage. Hence it was concluded that the optimized tablets have good stability during their shelf life.

\section{CONCLUSION}

In vitro delivery of more than $90 \%$ of Metoprolol over $12 \mathrm{~h}$ with nearly constant zero-order release kinetics was successfully achieved by optimization of the variables influencing the design of controlled porosity osmotic pump tablets of the drug with minimum expected potential of side effects. The rate of drug release from CPOP tablets could be tailored by controlling the osmotic pressure of the core tablet (osmogent type and drug/osmogent ratio), the composition of the coating solution, the membrane weight gain percentages, and the concentration of pore-forming agent.

\section{ACKNOWLEDGEMENT}

Authors are thankful to Mr.V. Anjaneyulu and Mr. Pavan, PhD Scholar, Kakatiya University, Warangal for their timely help and valuable support to carry out this research work. 
REFERENCES

1. Chien YW. Novel drug delivery systems: fundamentals, developmental concepts biomedical assessments. 1st ed. New york. Marcel Dekker; 2001

2. TW Lee,JR Robinson. The science and practice of Pharmacy. 2nd ed. . In Remington;

3. Verma RK, Garg S. Current status of drug delivery technologies and futuredirections. Pharm Techno. 2001;25(2):1-13.

4. Aulton, M. E. Pharmaceutics The Science of Dosage Form Design. Churchill Livingstone. 2002, $2^{\text {nd }}$ ed.414-418.

5. Ansel HC, Allen LV, Jr. Popovich NC. Pharmaceutical dosage forms and drug delivery systems. 7th ed. Baltimore: Lippincott Williams and Wilkins; 2000.

6. Mukeshgohel, R.Parik, Nillay. Osmotic Drug Delivery: An Update.2009.

7. Jain N.K, "Advances in Novel and Controlled Delivery", 18-39.

8. Banker SG, Rhodes TC. Modern Pharmaceutics. 2nd ed. New york Marcel Dekker; 1990

9. Vyas SP, Khar RK. Controlled drug delivery : concepts and advances. 1 st ed. Delhi. Vallabh Prakashan; 2002

10. $\mathrm{T}$ W Lee, J R Robinson. In Remington: The science and practice of pharmacy.2nd ed. Baltimore: Lippincott Williams and Wilkins; 2000.

11. Subrahmanyam CVS. Essential of physical pharmacy. 1st ed. Delhi: VallabhPrakashan; 2003.

12. Das $\mathrm{N}$ and Das $\mathrm{S}$. Controlled release of oral dosage forms formulation. Fill \&Finish; 2003:10-15.

13. Lachman L, Lieberman HA, Kanig JL. Theory and practice of industrial pharmacy. 3rd ed. Bombay.Varghese Publishing House; 1987.

14. Brahmankar DM, Jaiswal SB. Biopharmaceutics and pharmacokinetics a treatise. 1st ed. Delhi. VallabhPrakashan; 2005.

15. Ritschel WA. Biopharmaceutic and pharmacokinetics aspects in the design of controlled release ofperoral drug delivery systems. Drug Del Ind Pharm 1989;15:1073-1103. http://dx.doi.org/10.3109 103639048909043666

16. Ahmed Abd-Elbary, Mina Ibrahim Tadros, Ahmed Adel Alaa-Eldin Development and In Vitro/In Vivo Evaluation of Etodolac Controlled Porosity Osmotic Pump Tablets. AAPS PharmSciTech. June 2011;12: 2. http://dx.doi.org/10.1208/s12249-011-9608-z

17. Chinmaya Keshari Sahoo, Tanmaya Keshari Sahoo, Alok Kumar Moharana , Kanhu Charan Panda.Formulation and optimization of porous osmotic pump-based controlled Release system of Residronate Sodium for the treatment of postmenopausal osteoporosis, International Journal of Pharmaceutical Sciences Review and Research. January February 2012;2(1):021.
18. Kazuto O, Atsuo O, Rinta I, Osamu A, Norio O, Tetsumi I et al. Design and evaluation of an osmotic pump tablet (OPT) for chlorpromazine using (SBE)7M- $\beta$ - CD. Pharm Res. 1999;16(4):549-552. http:// dx.doi.org/10.1023/A:1018827214223

19. Kumar P, Singh S, Mishra B. Drug delivery system of Ranitidine Hydrochloridebased on osmotic technology: development and evaluation. Current Drug Delivery.2008;5:332-42 http://dx.doi.org/ $10.2174 / 156720108785914943$

20. Longxiao L, Jinchao W, Suyan Z. Delivery of Prazosin Hydrochloride from osmotic pump system prepared by coating the core tablet with an indentation. Drug Delivery. 2007;14:21-24.

21. Longxioa L, Xiangning X. Preparation of bilayer-core osmotic pump tablet by coating the indented core tablet. Int J Pharm. 2008;352:225230. http://dx.doi.org/10.1016/j.ijpharm.2007.10.047

22. Longxioa L, Xiaociu W. Solubility-modulated monolithic osmotic pump tablet for atenolol delivery. Eur J Pharm Biopharm. 2008;68:298-302. http://dx.doi.org/10.1016/j.ejpb.2007.04.020

23. Longxioa L, Jeong K, Gilson K, Bong L, John MR, Hai BL. Nifedipine controlled delivery by sandwiched osmotic tablet system. J Control Release.2000;68:145-156.http://dx.doi.org/10.1016/S01683659(00)00243-1

24. Meena rani, Rahul S, Chelladurai S, Brahmeshwar M. Development and Biopharmaceutical Evaluation of Osmotic Pump Tablets for Controlled Delivery of Diclofenac Sodium. 2003: 263 - 273

25. Mishra B, Srivastava S, Singh S, Sankar C. Oral osmotic pumps for poorly water soluble drug-Rofecoxib: formulation development perspective. Ind Drugs.2006;43(7):553-561.

26. Motilal M.,Damodaran N. Formulation and invitro evaluation of osmotic drug delivery system of Metoprolol Succinate. International journal of Pharmacy and pharmaceutical Sciences.2010;2(2):5

27. Mukesh C. Gohel, Rajesh K .Parikh, Stavan A. Nagori,and Dillip G.Jena. Fabrication of Modified Release Tablet Formulation of Metoprolol Succinate using Hydroxypropyl Methyl cellulose and Xanthan Gum..AAPS Pharm Sci Tech.2009;10(1):62-69 http:// dx.doi.org /10.1208/s12249-008-9174-1

28. Nurten Ozdemir, Jfilide Sahin. Design of a controlled release osmotic pump system of ibuprofen. International Journal of Pharmaceutics.1997;1(58):91-97 http://dx.doi.org/10.1016/S03785173(97)00250-0

Cite this article as:

Veeramalla Anil Kumar, Madishetty Vamshikrishna,Indarapu Rajendra Prasad, Gudikandula Raj Kumar, Kadari Srinivas. Development and in-vitro evaluation of Metoprolol succinate controlled porosity osmotic pump tablets. Int. Res. J. Pharm. 2013; 4(4):176-184 